\title{
New Rb-Sr mineral ages temporally link plume events with accretion at the margin of Gondwana
}

\author{
M. J. Flowerdew, ${ }^{1}$ J. S. Daly, ${ }^{2}$ and T. R. Riley ${ }^{3}$ \\ ${ }^{1}$ British Antarctic Survey, Madingley Road, High Cross, Cambridge, CB3 0ET, UK (mf@bas.ac.uk) \\ ${ }^{2}$ School of Geological Sciences, University College Dublin, Belfield, Dublin 4, Ireland (stephen.daly@ucd.ie) \\ ${ }^{3}$ British Antarctic Survey, Madingley Road, High Cross, Cambridge, CB3 0ET, UK (t.riley@bas.ac.uk)
}

\begin{abstract}
Five of six Rb-Sr muscovite mineral isochron ages from the Scotia Metamorphic Complex of the South Orkney Islands, West Antarctica, average $190 \pm 4$ Ma. The muscovite ages are interpreted to date foliation-formation and thus also accretion and subduction at the Gondwana margin. Coincident picrite and ferropicrite magmatism, indicative of melts from deep-seated depleted mantle, permits a causative link between accretion and the arrival of the Karoo - Ferrar - Chon Aike mantle plume in the Early Jurassic. Three biotite $\mathrm{Rb}$-Sr mineral isochron ages are consistently younger and average $176 \pm 5 \mathrm{Ma}$. The biotite ages may record post-metamorphic cooling or more likely retrogressive metamorphic effects during uplift.
\end{abstract}

Citation: Flowerdew, M.J., J.S. Daly and T.R. Riley (2007), New Rb-Sr mineral ages temporally link plume events with accretion at the margin of Gondwana. A Keystone in a Changing World - Online Proceedings of the $10^{\text {th }}$ ISAES, edited by A.K. Cooper and C.R. Raymond et al., USGS OpenFile Report 2007-1047, Short Research Paper 012, 4 p.; doi:10.3133/of2007-1047.srp012.

\section{Introduction}

Despite prolonged subduction since the Mesozoic, less sediment than expected has been accreted onto the northern Antarctic Peninsula and southern South American continent margins. Tectonic erosion during subduction (Hervé and Fanning 2003) or the subsequent removal of accreted material during transpression (Vaughan and Livermore 2005), could explain the volumetrically small proportion of preserved accreted material. Moreover, Vaughan and Livermore (2005) proposed that short-lived stress increases at plate boundaries, caused by the arrival of mantle plumes at the base of the lithosphere, may have controlled accretion, e.g., spanning the TriassicJurassic boundary and in the mid-Cretaceous.

Accurately establishing the timing of accretion to the South American and Antarctic Peninsula Gondwana margin is difficult because of the paucity of fossils and overstepping unconformities, and the lack of crosscutting intrusions. Instead, detrital mineral geochronology has been used to provide maximum depositional ages and limits on accretion (Hervé et al., 2003a, b).

This study focuses on the timing of accretion of the Scotia Metamorphic Complex, an accretionary complex on the South Orkney Islands (Fig. 1; Tanner et al., 1982; Dalziel 1984). Existing K-Ar (Tanner et al., 1982; Rex 1976; Grikurov et al., 1967; Miller 1960) and Ar-Ar mineral ages (Grunow et al., 1992) suffer from extraneous argon and are open to interpretation. Critically the range of ages obtained (204 Ma - $176 \mathrm{Ma}$ ) spans two major plume events the Late Triassic Central Atlantic Magmatic Province and the Early Jurassic Karoo - Ferrar - Chon Aike episode - such that any causal link is difficult to determine. Where extraneous argon is prevalent, $\mathrm{Rb}-\mathrm{Sr}$ geochronology can be a viable alternative (Willigers et al., 2004). This paper presents new Rb-Sr muscovite and biotite ages in order to determine whether accretion correlates with either of the plume events.

\section{Geology of the South Orkney Islands}

The Scotia Metamorphic Complex (Tanner et al., 1982) of the South Orkney Islands differs from many other accretionary complexes in the Scotia Sea region in its higher metamorphic grade and unconformable contact with overlying fossiliferous sequences. The predominantly semi-pelitic complex contains marble and garnetiferous quartzites (metacherts) as well as abundant metabasites with an enriched-type MORB and alkaline ocean-island basalt chemistry (Storey and Meneilly 1985). On Signy Island (Fig. 1), metamorphic conditions are estimated to be $8 \mathrm{kbar}$ and $545^{\circ} \mathrm{C}$ (Storey and Meneilly 1985). The complex is interpreted as a tectonic mixture as blastomylonitic zones within the complex are thought to separate oceanic (including metabasite lithologies) and continental material (Storey and Meneilly 1985). Based on the appearance of metabasite lithologies (Trouw et al., 1997a), the junction with the Greywacke Shale Formation, a sedimentary protolith with a wholly continental provenance (Andreis et al., 1997), is thought to occur on eastern-most Coronation Island. On Powell Island, the metamorphic grade increases from anchizone ( $c$. $4 \mathrm{kbar}$ at $275^{\circ} \mathrm{C}$ ) through the biotite and garnet isograds reaching conditions similar $\left(c .7 \mathrm{kbar}\right.$ at $\left.500^{\circ} \mathrm{C}\right)$ to those of Signy (Trouw et al., 1997a, b) consistent with the juxtaposition of the Greywacke Shale Formation with the Scotia Metamorphic Complex metamorphism during accretion.

The Greywacke Shale Formation and Scotia Metamorphic Complex also share an early polyphase 
tectonic history (Meneilly and Storey 1986; Trouw et al., 1997a). The second phase of deformation resulted in a pervasive mineral lineation and mica foliation accompanying growth of relatively high pressure - low temperature metamorphic assemblages, believed to have formed as a result of south-directed (present coordinates) subduction (Trouw et al., 1997a).

\section{Timing of subduction and accretion}

Unconformable sequences are exposed in two separate areas on Powell and Coronation Islands (Fig. 1) but, despite similar sedimentological characteristics, yield different apparent stratigraphical ages. The macrofossil fauna of the Coronation Island sequences indicate a late Jurassic to Early Cretaceous age (Thomson and Willey 1975). A fossil flora from the Powell Island Conglomerate is considered EarlyMiddle Jurassic (Cantrill 2000) and is correlated with the Botany Bay flora dated at $c .167 \mathrm{Ma}$ by Hunter et al. (2005). Until the stratigraphic age is confirmed, minimum age estimates for accretion are open to interpretation.

Chert from Scapa Rock, within the outcrop area of the Greywacke Shale Formation (Fig. 1), contains Late Triassic radiolaria (Dalziel et al., 1981). Its value as a maximum age limit for accretion is compromised, however, due to the large stratigraphic range for this fauna. $\mathrm{Rb}-\mathrm{Sr}$ and $\mathrm{K}-\mathrm{Ar}$ whole rock age determinations (Fig. 2; Tanner et al., 1982; Trouw et al., 1997a, b), although somewhat unreliable due to imprecision or lack of control on extraneous argon, support the radiolarian fossil evidence and suggest accretion of Permian-Triassic protoliths. Direct dating of metamorphic minerals (Fig. 2) has yielded equivocal results due to lack of confidence in the available $\mathrm{K}-\mathrm{Ar}$ and Ar-Ar ages (see above).

\section{Geochronology}

$\mathrm{Rb}-\mathrm{Sr}$ geochronology was carried out on micas that grew during the second regional tectonothermal event. In the schists, muscovite and biotite define the S2 foliation together with quartz-feldspar segregations. New mica growth is minimal during D3, e.g., F3 folds lack axial planar mica. Quartz but not feldspar is commonly recrystallized by D3. Within marbles, muscovite is randomly orientated as part of a coarse granular texture. D3 involves cataclasis and thus the dated micas are considered to be MS2 in age. Metabasites have an amphibolite, epidote and plagioclase foliation with MP2 biotite porphyroblasts.

$\mathrm{Rb}$-Sr analyses (Table 1) were undertaken at the School of Geological Sciences, University College Dublin, Ireland. 99\% pure handpicked mineral separates (c. $0.03 \mathrm{~g}$ ), were spiked with a mixed ${ }^{85} \mathrm{Rb}$ ${ }^{84} \mathrm{Sr}$ spike and dissolved in a 5:1 $\mathrm{HF}$ and $\mathrm{HNO}_{3}$ acid mixture. Chemical separation of $\mathrm{Sr}$ used TruSPEC resin whilst separation of $\mathrm{Rb}$ used traditional chromatography. $\mathrm{Rb}$ and $\mathrm{Sr}$ were analysed on modified VG Micromass 30 and VG 354 thermal ionisation mass spectrometers, respectively. $\mathrm{Rb} / \mathrm{Sr}$ uncertainty is estimated to be $1.5 \%$ based on repeat analysis of the SRM $607 \mathrm{~K}$-feldspar standard, while the ${ }^{87} \mathrm{Sr} /{ }^{86} \mathrm{Sr} 2 \sigma$ analytical uncertainties in Table 1 were used for age calculations (Figs 1, 2). During analysis the SRM 987 Sr standard yielded a ${ }^{87} \mathrm{Sr} /{ }^{86} \mathrm{Sr}$ ratio of $0.710241 \pm 18$ $(2 \sigma, \mathrm{n}=6)$. Ages were calculated using the ${ }^{87} \mathrm{Rb}$ decay constant of $1.42 \times 10^{-11}$ (Steiger and Jäger 1977).

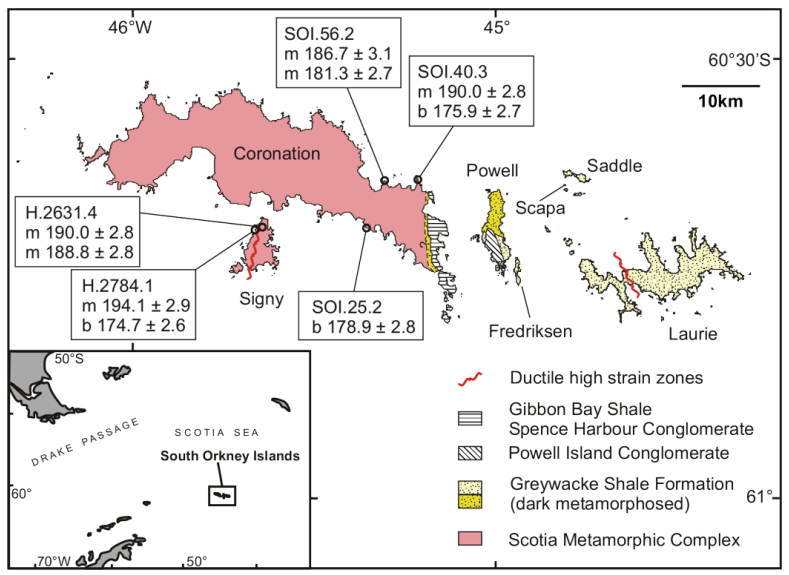

Figure 1. Geology sketch map, sample locations and results of $\mathrm{Rb}-\mathrm{Sr}$ geochronology. $\mathrm{m}=$ muscovite isochron age, $\mathrm{b}=$ biotite isochron age.

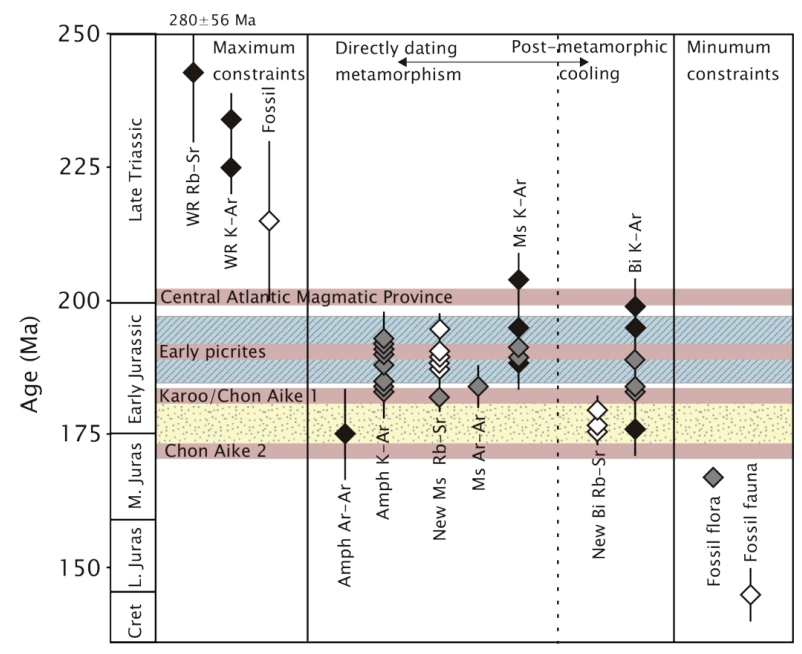

Figure 2. Summary of time constraints for accretion and comparison with plume-related events. Horizontal panels: grey $=$ plume events, blue/diagonal = time of accretion, yellow/stipple $=$ uplift. Diamonds: open $=$ reliable, grey $=$ possibly reliable, black $=$ unreliable.

\section{Discussion}

Validity and interpretation of the geochronology

The low $\mathrm{Rb} / \mathrm{Sr}$ ratios for muscovite (Table 1) mean that reliable ages are dependent on isotopic equilibrium 
Table 1. Rb-Sr geochronology

\begin{tabular}{|c|c|c|c|c|c|c|c|c|}
\hline Sample & Lat. Long. Min.* & (pin & (pppin) & $\mathbf{R b} /{ }^{86} \mathrm{Sr}$ & ${ }^{87} \mathrm{Sr} /{ }^{86} \mathrm{Sr} \quad( \pm 2 \sigma)$ & isochron & Age $( \pm 2 \sigma)$ & ${ }^{87} \mathbf{S r}^{86}{ }^{8} \mathbf{S r}_{\mathbf{i}}$ \\
\hline \multirow{4}{*}{$\begin{array}{l}\text { H.2631.4 } \\
\text { marble }\end{array}$} & $60.68-45.63 \mathrm{~ms}$ & 184.85 & 75.57 & 7.09 & $0.726559(29)$ & \multirow[t]{2}{*}{$\mathrm{ms}-\mathrm{cal}$} & \multirow[t]{2}{*}{$190.0(2.8)$} & \multirow[t]{2}{*}{0.707408} \\
\hline & cal & 0.14 & 425.28 & 0.0009 & $0.707411(14)$ & & & \\
\hline & $\mathrm{ms} \mathrm{r}$ & 213.41 & 76.60 & 8.08 & $0.729109(16)$ & \multirow[t]{2}{*}{$\mathrm{ms} \mathrm{r}-\mathrm{cal} \mathrm{r}$} & \multirow[t]{2}{*}{$188.8(2.8)$} & \multirow[t]{2}{*}{0.707424} \\
\hline & cal $\mathrm{r}$ & 0.28 & 434.19 & 0.0019 & $0.707429(16)$ & & & \\
\hline \multicolumn{2}{|c|}{ Н.2784.1 -60.69-45.64ms } & 324.24 & 115.62 & 8.13 & $0.729505(23)$ & \multirow{3}{*}{$\begin{array}{l}\mathrm{ms}-\mathrm{pl} \\
\mathrm{bt}-\mathrm{pl}\end{array}$} & \multirow{3}{*}{$\begin{array}{l}194.1(2.9) \\
174.7(2.6)\end{array}$} & \multirow{3}{*}{$\begin{array}{l}0.707066 \\
0.707117\end{array}$} \\
\hline \multirow[t]{2}{*}{ semi-peli } & bt & 351.45 & 18.70 & 55.11 & $0.843982(49)$ & & & \\
\hline & $\mathrm{pl}$ & 7.76 & 121.65 & 0.18 & $0.707575(16)$ & & & \\
\hline \multicolumn{2}{|c|}{ SOI.40.3 -60.63 $-45.19 \mathrm{bt}$} & 410.03 & 53.65 & 22.24 & $0.766787(46)$ & \multirow{3}{*}{$\begin{array}{l}\mathrm{bt}-\mathrm{pl} \\
\mathrm{ms}-\mathrm{pl}\end{array}$} & \multirow{3}{*}{$\begin{array}{l}175.9(2.7) \\
187.7(4.0)\end{array}$} & \multirow{3}{*}{$\begin{array}{l}0.711164 \\
0.711029\end{array}$} \\
\hline \multirow[t]{2}{*}{ semi-peli } & $\mathrm{ms}$ & 262.29 & 217.79 & 3.49 & $0.720338(19)$ & & & \\
\hline & $\mathrm{pl}$ & 13.96 & 50.22 & 0.80 & $0.713176(54)$ & & & \\
\hline SOI.5 & $-60.62-45.32 \mathrm{~ms}$ & 254.74 & 208.46 & 3.54 & $0.716655(16)$ & \multirow[t]{2}{*}{$\mathrm{ms}-\mathrm{cal}$} & \multirow[t]{2}{*}{$186.7(3.1)$} & \multirow[t]{2}{*}{0.707259} \\
\hline \multirow[t]{3}{*}{ marble } & cal & 2.06 & 878.31 & 0.0068 & $0.707277(71)$ & & & \\
\hline & $\mathrm{ms} \mathrm{r}$ & 262.43 & 209.41 & 3.63 & $0.716609(17)$ & \multirow[t]{2}{*}{$\mathrm{ms} \mathrm{r}-\mathrm{cal} \mathrm{r}$} & \multirow[t]{2}{*}{$181.3(2.7)$} & \multirow[t]{2}{*}{0.707255} \\
\hline & $\mathrm{cal}$ & 3.69 & 855.74 & 0.0125 & $0.707287(17)$ & & & \\
\hline \multicolumn{2}{|c|}{ SOI.25.2 -60.68 -45.36bt } & 306.25 & 28.48 & 31.36 & $0.790208(100)$ & \multirow[t]{2}{*}{$\mathrm{bt}-\mathrm{pl}$} & \multirow[t]{2}{*}{$178.9(2.8)$} & \multirow[t]{2}{*}{0.710450} \\
\hline metabas & $\mathrm{pl}$ & 0.99 & 13.08 & 0.22 & $0.711011(383)$ & & & \\
\hline
\end{tabular}

*Mineral abbreviations: $\mathrm{bt}=$ biotite, $\mathrm{cal}=$ calcite, $\mathrm{pl}=$ plagioclase feldspar, $\mathrm{ms}=$ muscovite, $\mathrm{r}=$ replicate analysis

between muscovite and the low $\mathrm{Rb} / \mathrm{Sr}$ phase. Despite textural equilibrium, isotopic disequilibrium could exist, as the two minerals are unlikely to have closed simultaneously (see below). The results are considered robust however, because ages from different lithologies, over a large area (Fig. 1), using different low $\mathrm{Rb} / \mathrm{Sr}$ phases (Table 1) are indistinguishable.

Assuming control by volume diffusion (Dodson 1973), the muscovite $\mathrm{Rb}-\mathrm{Sr}$ system would close at $c$. $500^{\circ} \mathrm{C}$ (Cliff 1985), around the maximum metamorphic temperature for the South Orkney rocks. More recent studies, as summarised by Villa (2006), illustrate a multitude of additional factors influencing closure, including mineral and fluid compositions, deformation, recrystallization and the proximity of sinks for daughter isotopes. It is our view that the muscovite ages from South Orkney record $\mathrm{Sr}$ isotopic equilibrium achieved by a combination of metamorphic fluidmineral interaction, recrystallization and mineral growth during D2 associated with subductionaccretion.

The lower $\mathrm{Rb} / \mathrm{Sr}$ and $\mathrm{Rb}$ concentrations and higher Sr concentrations in the South Orkney biotites (Table 1) may indicate disruption of a formerly closed system. However, the consistency of the ages suggests meaningful results, though their geological significance is unclear. It is possible that the ages record fluid interaction during uplift, accompanied by minor chloritisation. Thus they should not be interpreted simply as dating cooling below $c .300^{\circ} \mathrm{C}$, the widely accepted closure temperature for biotite (Cliff 1985).

\section{Coincidence of plume events and accretion}

The Central Atlantic magmatic province produced voluminous tholeiitic volcanism at c. $200 \mathrm{Ma}$ (Nomade et al., 2007), which has been widely linked to the arrival of a mantle plume (Oyarzun et al., 1997), whilst the Karoo - Ferrar provinces had major basaltic volcanism at c. $182 \mathrm{Ma}$ (Riley and Knight 2001). The Chon Aike province was almost entirely silicic and was characterized by two main peaks of volcanism at $c .183$ Ma and c. 170 Ma (Pankhurst et al., 2000; Hunter et al., 2006). The $\mathrm{Rb}-\mathrm{Sr}$ ages reported here record accretion at c. $190 \mathrm{Ma}$, which is midway between the age of maximum volcanism of the Central Atlantic and Karoo - Ferrar provinces. Seemingly then, accretion at the margin is not coeval with impingement of either plume, a notion supported by geochronology from accretionary complexes elsewhere on the Gondwana margin (e.g. Féraud et al., 1997).

However, by looking at the dyke record of the Karoo - Ferrar volcanic province, a more complete picture of its evolution is revealed. Geochemistry from a suite of dykes (Riley et al., 2005) provides the strongest evidence that the province was, at least in part, related to the arrival of a mantle plume. The dykes include picrites and ferropicrites that were derived from deep-seated, depleted mantle, interpreted as melts from a mantle plume as it approached the base of the lithosphere (Riley et al., 2005). Ar-Ar geochronology (Riley et al., 2005) demonstrates that the picrites and 
ferropicrites, at $190 \mathrm{Ma}$, are significantly older than the main Karoo magmatic peak of $182 \mathrm{Ma}$.

\section{Summary}

Coincidence of the timing of metamorphism and the picritic magmatism at 190 Ma would appear to substantiate a causative link between plume initiation and accretion and provides further support for the Vaughan and Livermore (2005) model.

Acknowledgements: MJF acknowledges support from the crew of the Ernest Shackleton, staff at Signy base and field assistance from Liz Homer. M. Murphy is thanked for technical assistance with the $\mathrm{Rb}-\mathrm{Sr}$ analyses. Bob Pankhurst and co-editor John Gamble are thanked for their reviews, which have improved an earlier version of this paper.

\section{References}

Andreis, R. R., A. Ribeiro, and R. A. J. Trouw (1997), Remarks on the petrofacies of Permo-Triassic turbidites from the Antarctic Peninsula, South Shetland and South Orkney Islands, in The Antarctic Region: Geological Evolution and Processes, edited by C. A. Ricci, pp.401-407, Tipografia Senese, Siena.

Cantrill, D. J. (2000), A new macroflora from the South Orkney Islands, Antarctica: evidence of an Early to Middle Jurassic age for the Powell Island Conglomerate, Ant. Sci., 12, 185-195.

Cliff, R. A. (1985), Isotopic dating in metamorphic belts, J. Geol. Soc. Lond, 142, 97-110.

Dalziel, I. W. D., D. H. Elliot, D. L. Jones, J. W. Thomson, M. R. A. Thomson, N. A. Wells, and W. J. Zeinsmeister (1981), The geological significance of some Triassic microfossils from the South Orkney Islands, Scotia Ridge, Geol. Mag., 118, 15-25.

Dalziel, I. W. D. (1984), Tectonic evolution of a forearc terrane, southern Scotia ridge, Antarctica, Geol. Soc. Am. Special Paper, 220, 32pp.

Dodson, M. H. (1973), Closure temperatures in cooling geochronological and petrological systems, Cont. Min. Pet., 40, 259-274.

Féraud, G., F. Hérve, D. Morata, V. Muñoz, and R. Toloza (1997), Scotia metamorphic complex, Antarctica: evidence for the diachronous build-up of a subduction complex. IX Congr. Geol. Chileno, resum expand 2, 374-377.

Grikurov, G. E., A. Y. Krylov and Y. I. Silin, (1967), Absolute age of some rocks from the Scotia arc and Alexander I Land (western Antarctica), Akademiya Nauk SSSR Doklady, Earth Science Section, English translation, 19-22.

Grunow, A. M., I. W. D. Dalziel, T. M. Harrison, and M. T. Heizler, (1992), Structural geology and geochronology of subduction complexes along the margin of Gondwanaland: new data from the Antarctic Peninsula and southernmost Andes, Geol. Soc. Am. Bull., 104, 1497-1514.

Hervé, F. and C. M. Fanning (2003), Early Cretaceous subduction of continental crust at the Diego de Amagro archipelago, Southern Chile, Episodes, 26, 285-289.

Hervé, F., C. M. Fanning, and R. J. Pankhurst (2003a), Detrital zircon age patterns and provenance of the metamorphic complexes of Chile, J. S. Am. E. Sci, 16, 107-123.

Hervé, F., Miller, H. and Pimpirev, C. (2003b), Patagonia Antarctica connections before Gondwana break-up, in Antarctica: contributions to global earth sciences, edited by D. K. Fütterer, D. Damaske, G. Kleinschmidt, H. Miller and F. Tessensohn, pp. 217228, Springer-Verlag, Berlin Heidelberg New York.

Hunter, M. A., T. R. Riley, D. J. Cantrill, M. J. Flowerdew, and I. L. Millar (2006), A new stratigraphy for the Latady Basin, Antarctic Peninsula: Part 1, Ellsworth Land Volcanic Group, Geol. Mag., 143, 777-796.
Hunter, M. A., D. J. Cantrill, M. J. Flowerdew, and I. L. Millar (2005), Middle Jurassic age for the Botany Bay Group: implications for Weddell Sea Basin creation and southern hemisphere biostratigraphy. J. Geol. Soc. Lond., 162, 745-748.

Meneilly, A. W. and B. C. Storey (1986), Ductile thrusting within subduction complex rocks on Signy Island, South Orkney Islands, J. Struct. Geol., 8, 457-472.

Miller, J. A. (1960), Potassium-argon ages of some rocks from the south Atlantic, Nature, 187, 1019-1020.

Nomade, S., K. B. Knight, E. Beutel, P. R. Renne, C. Verati, G. Féraud, A. Marzoli, N. Youbi, and H. Bertrand (2007), Chronology of the Central Atlantic Magmatic Province: implications for Central Atlantic rifting processes and the Triassic - Jurassic biotic crisis, Palaeogeogr. Palaeoclimatol. Palaeoecol., 244, 326-344.

Oyarzun, R., M. Dolbas, J. Lopez-Ruiz, and J. M. Cebria (1997), opening of the Central Atlantic and asymmetric mantle upwelling phenomena: implications for long lived magmatism in western North Africa and Europe, Geology, 27, 727-730.

Pankhurst, R. J., T. R. Riley, C. M. Fanning, and S. R. Kelley (2000), Episodic silicic volcanism in Patagonia and the Antarctic Peninsula: chronology of magmatism associated with the break-up of Gondwana, J. Pet., 41, 605-625.

Rex D. C. (1976), Geochronology in relation to the stratigraphy of the Antarctic Peninsula, Br. Antarct. Surv. Bull. 43, 49-58.

Riley, T. R. and K. B. Knight (2001), Age of pre-break-up Gondwana magmatism: a review, Ant. Sci., 13, 99-110.

Riley, T. R., P. T. Leat, M. L. Curtis, I. L. Millar, and A. Fazel. (2005), Early-Middle Jurassic dolerite dykes from western Dronning Maud Land (Antarctica): identifying mantle sources in the Karoo large igneous province, J. Pet., 46, 1489-1524.

Steiger, R. H. and E. Jäger (1977), Subcommission on geochronology; convention on the use of decay constants in geoand cosmochronology. E. Plan. Sci. Lett., 36, 359-362.

Storey, B. C. and A. W. Meneilly (1985), Petrogenesis of metamorphic rocks within a subduction-accretion terrane, Signy Island, South Orkney Islands, J. Met. Geol., 3, 21-42.

Thomson, M. R. A. and L. E. Willey (1975), fossils from the South Orkney Islands: I. Coronation Island, Br. Antarc. Surv. Bull., 40, 15-21.

Tanner, P. W. G., R. J. Pankhurst, and G. Hyden (1982), Radiomentric evidence for the age of the subduction complex in the South Orkney and South Shetland Islands. J. Geol. Soc. Lond., 139, 683-690.

Trouw, R. A. J., C. W. Passchier, L. S. A. Simões, R. R. Andreis, and C. M. Valeriano (1997a), Mesozoic tectonic evolution of the South Orkney Microcontinent, Scotia arc, Antarctica, Geol. Mag., 134, 383-401.

Trouw, R. A. J., R. J. Pankhurst, and A. Ribeiro (1997b), On the relation between the Scotia Metamorphic Complex and the Trinity Peninsula Group, Antarctic Peninsula, in The Antarctic Region: Geological Evolution and Processes, edited by C. A. Ricci, pp.383389, Tipografia Senese, Siena.

Vaughan, A. P. M. and R. A. Livermore (2005), Episodicity of Mesozoic terrane accretion along the Pacific margin of Gondwana: implications for superplume-plate interactions, in Terrane processes at the margins of Gondwana, edited by A. P. M. Vaughan, P. T. Leat and R. J. Pankhurst, Geol. Soc. Lond. Special Publications, 246, 143-178.

Villa, I. M. (2006), From nanometer to megameter: isotopes, atomicscale processes and continent-scale tectonic models, Lithos, 87, 155-173.

Willigers B. J. A., K. Mezger, and J.A. Baker (2004), Development of high precision $\mathrm{Rb}-\mathrm{Sr}$ phlogopite and biotite geochronology; an alternative to ${ }^{40} \mathrm{Ar} /{ }^{39} \mathrm{Ar}$ tri-octahedral mica dating, Chem. Geol. 213, 339-358. 